\title{
Increasing the Brand Awareness of Artotel Surabaya Using a Promotional Video
}

\author{
Sherin Gloria Ivanalim \\ English Department, Faculty of Letters, Petra Christian University \\ Surabaya, East Java, Indonesia \\ Email: sherin.ivanalim@gmail.com
}

\begin{abstract}
The problem related to Business Communication that I found at ARTOTEL Surabaya is poor brand awareness compared to the other hotels which has a good brand awareness such as Pop Hotel, Cleo Business Hotel, and Oval Hotel. Because of this problem, the focus is on increasing the brand through the hidden uniqueness of ARTOTEL Surabaya. In this way, the promotional video will be the solution. The contents of ARTOTEL Surabaya's promotional video are three USP and ending. The USP is about the location, the unique rooms, and the foods. There are some theories about brand awareness, branding, promotion, and promotional video. This promotional video can be a new innovation to promote the hotel since ARTOTEL Surabaya does not have a promotional video before. As a result, ARTOTEL Surabaya will have a good brand awareness as a hotel with a good hospitality and a touch of art.
\end{abstract}

Keywords: Brand Awareness, Branding, Promotion, Promotional Video

\section{INTRODUCTION}

The name of ARTOTEL Surabaya is from 'Art' and 'Hotel'. The founder, Erastus Radjimin, combined those two words with '+' symbol, so the logo became "AR+OTEL". ARTOTEL Surabaya is a three stars hotel. The location of ARTOTEL Surabaya is at Jalan Dr. Soetomo, 79-81, Tegalsari, Surabaya. According to its vision, "ARTOTEL strives to enhance guest experience and promote the Indonesian Contemporary Art to the world" ARTOTEL Surabaya has a purpose to perpetuate Surabaya's culture in Indonesia. ARTOTEL Surabaya is designed with colonial architecture to keep the prestigious surrounding area and combined with a touch of contemporary art. It is reflected on the grand staircase that is the center of attention of this hotel. ARTOTEL Surabaya.There are 100 studio rooms in ARTOTEL Surabaya, such as Sudio 30 as many as 2 rooms, Studio 25 as many as 10 rooms, and Studio 20 as many as 88 rooms. With that concept, ARTOTEL Surabaya invites corporate business and domestic traveler to enjoy the uniqueness of ARTOTEL Surabaya. Starting from teenagers and youth who love travelling and creating contemporary art, ARTOTEL Surabaya can fulfill their needs with unusual modern design and unforgetable stay experience in ARTOTEL Surabaya because each room has its different design. This hotel has 100 rooms which are called 'studio', ROCA Bar and Restaurant, fast WIFI connection, 'MEET SPACE' on second floor, and 'ART SPACE' with a small mini store at the lobby.

My internship program lasted from 4 September until 4 December, 2017. In this three months, I worked in Sales and Marketing Department as a Public Relation assistant. During my internship program, I knew that ARTOTEL Surabaya was different from other hotels. As the competitors of ARTOTEL Surabaya, the other hotels such as Midtown Hotel, Crown Prince Hotel, Pop Hotel, Cleo Business Hotel, and Oval Hotel, performed better in terms of location and promotion. Their location is at the main street of Basuki Rahmat and Diponegoro. One of the example is Oval Hotel. It is one of the three-star hotels in Surabaya which has a good promotion in their social media. In addition, this hotel has a good brand awareness in that the brand name is popular because of the location and the room. The location is in the main street of Diponegoro and the shape of the hotel is represented by the name, Oval Hotel. ARTOTEL Surabaya needs to show their brand name to represent its uniqueness. 
The problem related to Business Communication that I found at ARTOTEL Surabaya is poor brand awareness. After I interviewed seven guests, I found that ARTOTEL Surabaya has other uniquenesses which the other three stars hotel do not have. However, some people do not know the uniqueness before they simply come to the hotel. Mostly, customers said that they stayed at ARTOTEL Surabaya because they joined an event at the hotel and got a free voucher. Then, they used the free voucher and stayed at ARTOTEL Surabaya. From that stayed experience, they could try the service, the food, and the studio room. After they stay at ARTOTEL Surabaya, they said that ARTOTEL Surabaya should expose their uniqueness through its promotion. When I asked them about the promotion of ARTOTEL Surabaya, some of them said that ARTOTEL Surabaya was much focus on the events. They did not pay attention too much about the room and the food.

Because of this problem, the focus is on increasing the brand through the hotel's hidden uniqueness. Then, the promotional video will be the solution since ARTOTEL Surabaya does not have a promotional video. The respondents also said that the promotional video would show the uniqueness of the hotel, it would make the hotel become more popular, and it could attract people to come with so much information about the hotel. So far, the sales team uses a brochure. Whereas, ARTOTEL Surabaya has been improving their design, atmosphere, and services. ARTOTEL Surabaya also does not have any promotional video as their sales tool In other words, they need something new for their additional sales tool to attract their potential customers.

\section{METHODS}

The first thing that I did to start writing the company proposal was making an interview with some random guests in ARTOTEL Surabaya for their opinion about the hotel. This interview has a purpose to find the strengths and weaknesses of the hotel. From the interview with the seven guests, I got three USP (Unique Selling Point) as the strength of ARTOTEL Surabaya. In addition, I searched the testimonials from other guests through online application, Traveloka and Trip Advisor. I take this evidences to convince the hotel that the uniquenesses are important to be shown on the promotional video. I also can get the information about the weakness of the hotel. The next step is making the concept and the story board for the promotional video. Finally, the three uniqueness are the strategic location, the spacious room, and the various Indonesian food. After I found all results, I made the company proposal. In the end of the company proposal, I mentioned one price to cover the fee of promotional video and I compared to the other videographers on the internet which is more expensive than my videographer.

After I collected all those things, I made an appointment with the new Hotel Manager, the Sales Manager, and the Public Relation. Finally, on March 16, 2018, I met Mr. Dendy as the new Hotel Manager, Mr. Suhadi as the Sales Manager, and Ms. Grantika as the Public Relation who helped me to arrange the meeting schedule. I brought my company proposal and explain my plan in doing this project. They looked very interested in my idea and the concept. They said that they agreed about the result of the interview with some guests and the promotional video because they need a new sales tool besides the brochure. The final price is IDR. 7.000.000 after negotiating and considering my proposal. On the day I came to do the shooting process, I brought the letter of agreement and Ms. Grantika signed it as a formal agreement between me and ARTOTEL Surabaya.

The contents of ARTOTEL Surabaya's promotional video are three USP and ending. The USP is about the location, the unique rooms, and the foods. The keyword on the video will be in English because ARTOTEL Surabaya always uses English for their social media. The color of the keyword is white, orange, and black because those are the theme for ARTOTEL Surabaya. The promotional video will be used for the sales team as their additional sales tool and for the Public Relation. The long version video will be for the sales team. They will bring it for promoting ARTOTEL Surabaya in their presentation. Then, the video will be used for the Public Relation because it will be uploaded on Instagram and Facebook of ARTOTEL Surabaya. Before the Public Relation uploaded it, she will separate in every one minute and upload it multiple times on Instagram because Instagram only provides one minute video. By separating the video into two or three video, ARTOTEL Surabaya can have a full version promotional video to show all the uniquenesses. In addition, when the Public Relation met some medias, she can show about ARTOTEL Surabaya through the promotional video. After taking some steps above, there will be three USP on the promotional video. The parts and the orders are below: 


\begin{tabular}{|c|c|c|c|c|}
\hline USP & 1.) Location & $\begin{array}{l}\text { 2.) Unique } \\
\text { Rooms }\end{array}$ & 3.) Foods & 4.) Ending \\
\hline & $\begin{array}{l}\text { In the heart of } \\
\text { Surabaya City }\end{array}$ & Spacious Room & $\begin{array}{l}\text { Various Indonesian } \\
\text { foods }\end{array}$ & $\begin{array}{l}\text { - Quote: } \\
\text { "Earth } \\
\text { without art } \\
\text { is just eh" }\end{array}$ \\
\hline & & Instagramable spots & Fresh and delicious & $\begin{array}{l}\quad \text { Final CTA: } \\
\text { GOOD: Rooms, } \\
\text { Foods, Location }\end{array}$ \\
\hline & & Simple & & \\
\hline
\end{tabular}

ANALYSIS AND FINDINGS

The title of this final project is Increasing the Brand Awareness of ARTOTEL Surabaya Using a Promotional Video, so the main cornern is the brand awareness. Based on the book titled "Strategi Menaklukkan Pasar Melalui Riset Ekuitas dan Perilaku Konsumen" (2004, p. 54), Darmadi Durianto, Sugiarto, and Tony Sijintak said that "brand awareness is the ability of the potential customer to recognize, to remember a brand as the part of particular products categories." It means that people can recognize the brand automatically when they see or hear the brand name. Here, a brand awareness is the main cornern because ARTOTEL Surabaya has a problem with it. ARTOTEL Surabaya needs to make their brand become more popular because some people do not know about ARTOTEL Surabaya as three-star hotel.

For the problem that ARTOTEL Surabaya has, the promotional video will be the best solution to increse its brand awareness. In the promotional video, there will be some contents which emphasize the hidden uniqunesses. According to Ekaterina Walter and Jessica Gioglio (2014, p.34), the power of video is undeniable. It means a video can be a good visual storytelling for ARTOTEL Surabaya's by showing the USP (Unique Selling Point), the logo, and the tagline. USP is a conception to purchase products of a brand. It should be a clear and attractive message that people get from the promotional video (Hacley, 2010, p.35). Also, they said that the popularity and variety of the video platforms provides a prime opportunity to reach a large number of people and leave a lasting impression $(2014$, p.35). After watching the promotional video, people will have a new value and impression about ARTOTEL Surabaya.

For the concept of the promotional video, I choose three uniquenesses to be shown in that promotional video. There are some steps needed to create a good promotional video (Maguire, 2016). The basic step to start making a good promotional video is by deciding the goal. In this case, the goal of making a promotional video for ARTOTEL Surabaya is increasing the brand awareness. In that promotional video, there are some possible directions to make the promotional video, such as Introductory, Explanatory, Problem/solution, Narative, Drive Action, Product-focused, Testimonial, Endorsement, Informative, and Entertainment. Here, the promotional video of ARTOTEL Surabaya uses Drive Action. Next, the tone is artsy because the models feel youthful to stay and enjoy their experience in ARTOTEL Surabaya. Duration of the promotional video should be considered. If the video is too long, it will make the viewers feel bored. Besides, if the video is too short, the information or the important points cannot be shown. In the problem's case, there will long version which is about 2,39 second. Then, it will be uploaded in a comp-lete promotional video on Instagram and Facebook. In ARTOTEL Surabaya's promotional video, the visual style is real people. It shows from the actor and actresses who come to the hotel and enjoy the facilities. For the video style, I invited my friends, Fian, Venny, Lidea, and Josephine as the models of the promotional video to represent the feeling of youthful. I emphasize the cheerful impression and satisfy expression by staying at ARTOTEL Surabaya because mostly the guests are young people. Thre are some scenes in the hotel itself such as in Art Space Lobby, the studio rooms, ROCA Restaurant, and outside the hotel. The music background is from Morning Light Music with a title "Energetic Upbeat Pop". The products that is shown in the promotional video is rooms and Indonesian foods. The promotional video also use some properties such as a luggage, a book, cups, and bags. In the end of the video, there is a final call to action "Good Rooms, Good Foods, Good 
Location", so that the viewers can remember the uniquess of ARTOTEL Surabaya. Last but not least, script and storyboard is important to be the guideline for the shooting process.

In the beginning of the promotional video, I will show the location of ARTOTEL Surabaya by writing the full address of the hotel. Also, the view from above the hotel is important to be exposed, so that people can know the building and the place clearly. Secondly, I will show the three types of the rooms with different designs. First of all, I show Studio 30 which is very comfortable by showing a girl who reading a book on the sofa and on the bed. Then, I show Studio 20 which has a spacious room by showing two girls who play a pillow on the bed. From my respondents, they said that ARTOTEL Surabaya has a bigger room than the others. I also add a keyword "Instagramable" by showing the girls taking a selfie with the background of the room because the studio room has a unique and different design. In other words, ARTOTEL Surabaya provides a unique design room to their guests who love take a selfie. The last is studio 25 . This room has a simple design and a good view. Compared to other three star hotels in the heart of Surabaya, ARTOTEL Surabaya has spacious rooms and good sunlight from the window. The respondents gave their opinion that other hotels, such as Amaris Hotel and Cleo Business Hotel have a bad room because the room is dark without enough sunlight from the window.

Thirdly, it will show the various Indonesian food which is fresh and delicious. There are other foods in ARTOTEL Surabaya besides Indonesian food, such as Western food. However, most of the respondents said that the Indonesian food in ARTOTEL Surabaya is the better than the Western food. They also said that the Indonesian food is better than Crown Prince Hotel and Midtown Hotel because ARTOTEL Surabaya can fulfill the needs of Indonesian people to eat delicious Indonesian foods at ROCA Restaurant. There are five respondents who recommend to show the Indonesian food buffet. The menu is various and suitable for Indonesian tongue.

For the ending, I mentioned some places nearby the hotel, such as the shopping malls, amusement parks, and Juanda airport in terms of animation. By showing the places around the hotel, people can know where ARTOTEL Surabaya is. For example, the hotel is nearby the biggest and modern mall in Surabaya called Tunjungan Plaza. It will be easier for people to know the location. From the guests that I have interviewed before, I just knew that the location of ARTOTEL Surabaya is strategic and accessible compared to Amaris Hotel, Cleo Business hotel, and Pop Hotel. There are six respondents who said the location of the hotel is good. Also, from the testimonial of Traveloka and Trip Advisor, someone said about the strategic location. From that evidence, ARTOTEL Surabaya can compete with other three star hotels which is around ARTOTEL Surabaya. Then, I put an animation of the tagline of ARTOTEL Surabaya and mentioned again the three USP, so that the viewers can remember the unique points of ARTOTEL Surabaya.

\section{CONCLUSION}

In conclusion, I decided to make a promotional video for ARTOTEL Surabaya. The problem related to Business Communication that I found at ARTOTEL Surabaya is poor brand awareness. I found that ARTOTEL Surabaya has other uniquenesses which is other three stars hotel do not have. However, some people do not know the uniqueness before they come to the hotel. Mostly, the customers said that they stay at ARTOTEL Surabaya because they joined an event at the hotel and got a free voucher. Then, they used the free voucher and stay at ARTOTEL Surabaya. From that stay experience, they could try the service, the food, and the studio room. After they stay at ARTOTEL Surabaya, they said that ARTOTEL Surabaya should expose their uniqueness through its promotion. In other words, ARTOTEL Surabaya needs to increase their brand awareness to compete with other three-star hotels in Surabaya.

The main purpose of this promotional video is to show the uniqueness of ARTOTEL Surabaya, such as the strategic location, the studio rooms, and the Indonesian food. The video consists of all information about ARTOTEL Surabaya, so that the customers can look at the services and products in a new way through promotional video. The promotional video will show the location and the address of ARTOTEL Surabaya, the unique, spacious, and comfortable room, the delicious Indonesian food, and the tagline. Those USP will be shown by four people who stay and enjoy at ARTOTEL Surabaya as travellers.

I expect that the promotional video has benefits as a new innovation in promoting the hotel because it will show the various rooms called studio in ARTOTEL Surabaya. The 
promotional video can be a modern way to build the brand awareness of the hotel. Also, it will show the location, restaurant, and the atmosphere of ARTOTEL Surabaya, so people will recognize the uniqueness of ARTOTEL Surabaya in every scene. The promotional video should be copied by the hotel staffs on their gadget to multiple it. It is very easy to use by the sales team and hotel's staff when they want to promote ARTOTEL Surabaya. They also can upload it on their Instagram and Facebook.

The processes leading to the creation of this tool is not that easy. There are some challenges that I need to get the project in ARTOTEL Surabaya such as started from being the internship student in Marketing Department which is a new experience for me, finding the problems in the hotel, writing the proposal, convincing the hotel staffs to approve the project, negotiating about the price, meeting the hotel's people, communicating my concept to the professional videographer, and editing the video repeatedly.

The suggestion for the next EBC students when they do a similar project in the future is they have to be respectful in their internship place because it can be the place where they do the final project. The other important things are being communicative and creative. In my experience as Public Relation assistant, my supervisor is like my best friend and my partner. We can talk about anything and job in the same time and maintain a good relation after I finished my internship program. Also, my supervisor taught me to be a creative person in every job later. In other words, the internship program is the first preparation. Building team work, being respectful, learning by doing, are the tips in marketplace. The result will be positive when I want to help the hotel by making a promotional video, although the negotiation of the price is not easy. The hotel supported and provided anything for me in the shooting process. Lastly, EBC students should be adaptable because by doing this Business Communication Final Project will force them to meet and work with new people.

\section{ACKNOWLEDGEMENTS}

First of all, I am so thankful to Jesus Christ because with His grace and His unconditional love, I could finish this Business Communication Final Project on time. It felt so hard before, but thankfully God gave me strengths and lovely people around me.

Secondly, I would like to say big thanks to my advisor, Drs. Jusuf Imam Ibrahim, MTESL who gave me a lot of positive advice, guidence, and help in doing my Business Communication Final Project. Without his guidence in other classes until making this final project, I could not work well. I would never forget his kindness and his motivational words in every class.

Thirdly, I want to express my gratitude to special people in my life such as my parents in Kertosono who have supported me through both financially and spiritually. I also thank my grandmother who always supports and prays for me through every phone call.

Fourthly, I would thank to my boyfriend, Andreas, who supported and accompanied me in my hard times. Also, I would thank my final project classmates: Vania, Evelina, Christina, and Merco, for supporting each other and spending our hard times in making this Business Communication Final Project. For my best mates: Monica, Venny, and Jofe, thank you for coloring my college life and being my best friends ever. For my home, South Youth 23: Fian, Kime, Charlie, Selin, and people who pray and support me spiritually, I am so grateful to have you all.

Lastly, thanks to ARTOTEL Surabaya for allowing me to do my internship program, gave me a lot of experiences, and involved me in some events. Also, it was a great opportunity to make my Business Communication Final Project in ARTOTEL Surabaya.

\section{REFERENCES:}

Durianto, D. Sugiarto. And Sijintak, T. (2004). Strategi Menaklukkan Pasar Melalui Riset Ekuitas dan Perilaku Merek. Last retrieved on June 5, 2018, from: https://books.google.co.id/books?id=bfhUJTSbapEC\&printsec=frontcover\&dq=Strategi + Menaklukkan+Pasar + Melalui + Riset + Ekuitas + dan + Perilaku + Konsumen\&hl=id\&sa $=$ X\&v ed=0ahUKEwid1PT3obbAhUJQ48KHZVaDQkQ6AEIKDAA\#v=onepage \&q=Strategi\%20Menaklukkan\%20P asar\%20Melalui\%20Riset\%20Ekuitas\%20dan\%20Perilaku\%20Konsumen\&f=false 
Hackley, C. (2010). Advertising and Promotion (2nd ed). London: SAGE Publications Ltd

Maguire, A. (2016). 8 Steps Creating a Promotional Video. Last retrieved on June 8, 2018, from: https://medium.com/swlh/how-to-create-a-promotional-video-707fa7a63019

Walter, E and Gioglio, J. (2014). The Power of Visual Storytelling. USA: McGraw-Hill Eduacation Books 